\title{
Max Weber possui duas sociologias? Análise comparativa do esquema conceitual de Sobre algumas categorias da sociologia compreensiva (1913) e Conceitos sociológicos fundamentais (1921)
}

Bruna dos Santos Bolda'

\section{Resumo}

A republicação crítica da obra de Max Weber, a Max Weber-Gesamtausgabe, suscitou o debate sobre as mudanças e as permanências do léxico weberiano. Um exemplo é a controvérsia entre os ensaios Kategorien (1913) e Grundbegriffe (1921). Schluchter (2014) defende que houve somente um refinamento do léxico, sem mudança de concepção. Lichtblau (2015) argumenta que houve mudança de abordagem: em 1913, histórica; em 1921, sociológica. À vista desse embate, objetiva-se identificar e discutir as implicações analíticas das alterações conceituais realizadas por Weber em Kategorien e em Grundbegriffe a fim de compreender o desenvolvimento de sua concepção de Sociologia. Reconhece-se a existência de um modelo micro-macro tanto em Kategorien quanto em Grundbegriffe. Mas é necessário esclarecer que os textos passaram por um processo de amadurecimento teórico e de aperfeiçoamento conceitual, tendo em vista a modificação do conteúdo conceitual de algumas categorias fundamentais do esquema weberiano.

Palavras-chave: Max Weber. Kategorien. Grundbegriffe.

Mestre em Sociologia Política pela Universidade Federal de Santa Catarina (UFSC) e doutoranda em Sociologia e Ciência Política na mesma instituição. Em ambos os cursos foi bolsista CNPq. E-mail: bruna.bolda@hotmail.com. Pesquisa desenvolvida com o apoio do CNPq.

\section{$(\mathrm{cc}) \mathrm{Br}$}

Direito autoral e licença de uso: Este artigo está licenciado sob uma Licença Creative Commons. Com essa licença você pode compartilhar, adaptar, para qualquer fim, desde que atribua a autoria da obra, forneça um link para a licença, e indicar se foram feitas alterações. 


\section{Introdução}

A busca por compreender o que Weber quis dizer demonstra que seu pensamento ainda engendra intensas discussóes no âmbito da Teoria Social. No Japão (ORIHARA, 2003), na Itália (ROSSI, 2007), na França (GROSSEIN, 2005a, 2005b; COLLIOT-THÉLÈNE, 2003; KAUFMANN, 2004), no México (VILLEGAS, 2014), nos países da América Latina (SELL, 2014b, 2018) ou nos Estados Unidos (KALBERG, 2012), a interpretação especializada em Max Weber "ressoa" os "ecos" da Weber-Renaissance $e^{2}$. Especialmente os estudos motivados pelo empreendimento de republicação crítica dos escritos weberianos, a Max WeberGesamtausgabe (MWG), ganharam visibilidade no cenário internacional.

Se por largos anos os especialistas se ocuparam com a exegese weberiana (especialmente a primeira geração da Universidade de Heidelberg, em meados da década de 1970), hoje os esforços centram-se na atualização de seus escritos. O "paradigma weberiano" defendido por Gert Albert et al (2003) e o "programa de pesquisa" de orientação weberiana proposto por Schluchter (2005) são exemplos dessa iniciativa. Essas discussóes contemporâneas sobre a obra de Max Weber, particularmente as que questionam as possibilidades de microrredução existentes nos escritos do autor - como os estudos de Gert Albert (2016), Thomas Schwinn (1993), Rainer Lepsius (2013), Stefan Breuer (1991) e Schluchter (2005)3 que, com base em uma análise comparativa dos níveis [Mehrebenenanalyse] dos estudos empíricos e dos textos metodológicos, discutem as propriedades emergentes dos escritos weberianos - revelam perspectivas por algum tempo obscurecidas. Eles contestam o clássico estatuto do "Weber individualista metodológico"

2 Em meados da década de 1970, as discussões sobre Weber foram tomando novos contornos. Reinhard Bendix e Guenther Roth, emigrados alemães estabelecidos na América do Norte, contestaram explicitamente a interpretação e as traduções parsonianas. Por meio de estudos exegéticos e hermenêuticos, recuperaram a dimensão histórica e política da teoria de Weber. Stephen Kalberg (1994), por sua vez, em crítica à abordagem historicista de Bendix, vem desenvolvendo interpretações sobre o método weberiano. Seu esforço se centra sob a discussão genuinamente sociológica de Weber (SELL, 2013). O esforço de Bendix e Roth, juntamente com Tenbruck, Habermas e Schluchter (para citar alguns), sinalizou a primeira fase da Weber-Renaissance - um movimento teórico que traz à centralidade, novamente, as discussões sobre Weber na Alemanha.

3 De acordo com Schluchter (2005), a primeira demonstração dos níveis de análise da obra de Weber foi desenvolvida por David McClelland (196I). Ele analisou Die protestantische Ethik [A ética protestante], a fim de demonstrar a existência do "modelo de banheira". 
a ponto de advogar, por exemplo, por uma terceira via que admite tanto a determinação do nível micro quanto do nível macro (ALBERT, 2016). Algo que, nas palavras de Carlos Sell (2014a), ajuda a "desfossilizar" a obra de Weber.

Inserido nesse cenário de discussão, um dos debates fomentados pela Max Weber-Gesamtausgabe é o das permanências e das mudanças dos escritos de Weber. Há uma disputa teórica em torno da interdependência ou da disparidade entre os ensaios metodológicos de Weber, nomeadamente, Sobre algumas categorias da Sociologia Compreensiva [Über einige Kategorien der Verstehenden Soziologie] (1913) ${ }^{4}$ e Conceitos Sociológicos Fundamentais [Soziologische Grundbegriffe] (1921). O próprio Weber esclarece, na nota preliminar de Grundbegriffe que "Gegenüber dem Aufsatz im Logos IV (1913) ist die Terminologie tunlichst vereinfacht und daher auch mehrfach verändert, um möglichst leicht verständlich zu sein" (MWG I/23, [19191920], 2013, p. 1)5. Quer dizer, ele não pretendeu algo completamente novo com o texto de 1921. De um texto para outro houve, efetivamente, uma simplificação [vereinfacht] e uma atualização. Schluchter (2014, p. 195), em consonância com o argumento da nota preliminar do texto de 1921, defende que entre os dois textos há somente um refinamento do aparato léxico, e, portanto, não há "duas Sociologias" distintas entre si: “[...] de fato, 'Conceitos sociológicos fundamentais' apresenta, em relação ao escrito 'Categorias', uma terminologia mais compreensível e simplificada”.

Um exemplo de simplificação de terminologia e de refinamento do aparato léxico é o conceito de relação social. Tanto em Kategorien (1913) quanto nos Grundbegriffe (1921) há as noções de ação [Handeln], ordem [Ordnung] e organização [Verband]. Mas é somente no texto de 1921 que a noção de relação social [soziale Beziehung] é conceituada e seus subtipos [Vergemeinschaftung e Vergesellschaftung] desenvolvidos em profundidade. A ideia da relação social, aliás, já estava presente no texto de 1913, embora implicitamente, sob a categoria de ação societária [Gesellschaftshandeln] e ação por acordo [Einverständnishandeln] (SCHLUCHTER, 2014).

\footnotetext{
Doravante, Kategorien.

5 “Em comparação com o artigo 'Über einige Kategorien der Verstehenden Soziologie’ em Logos IV (1913), a terminologia foi oportunamente simplificada e, portanto, modificada em vários pontos para ser mais compreensivel" (WEBER, 2015, p. 3).
} 
Schluchter (2014) assegura que Grundbegriffe (1921) substitui Kategorien (1913), do ponto de vista da história da obra; afinal, ambos os textos desempenham o mesmo papel de introduzir o leitor de Wirtschaft und Gesellshaft $(W u G)^{6}$ aos métodos e conceitos da Sociologia Compreensiva. A diferença entre esses textos é que o de 1921 foi desenvolvido para introduzir um conjunto de textos de mesmo arcabouço conceitual (os textos escritos para $W u G$ no período pós-Guerra) ${ }^{7}$. Já o texto de 1913 , sob a perspectiva de Schluchter (2014), apesar de inicialmente ser escrito como introdução à parte antiga da $W u G$, não está situado em um conjunto de textos coerentes e de mesmo aparato conceitual. Isso porque os textos escritos antes da Primeira Guerra Mundial são de diferentes fases e características.

Klaus Lichtblau (2015), por outro lado, argumenta que os dois textos em questão possuem diferentes abordagens. Ao longo de sua trajetória intelectual, o interesse de Weber foi gradualmente se deslocando de uma ciência individualizante (histórica) ${ }^{8}$ para uma ciência generalizante (sociológica). À vista disso, Lichtblau afirma que a Sociologia pré-Guerra de Weber - como o texto Kategorien (1913) - é orientada por uma teoria dos estágios de desenvolvimento, ainda em proximidade com a história do desenvolvimento. Já no texto de 1921, Weber evidentemente distancia a Sociologia e a História. O autor caracteriza a Sociologia como a ciência que atenta para as generalidades dos fenômenos sociais e para os significados das orientações das açóes. Com base nisso, Lichtblau (2015) afirma que a Sociologia Compreensiva de Weber não é a mesma em 1913 e em 1921. Weber formulou, ao longo de seus escritos, duas Sociologias distintas: uma de característica individualizante, em conexão com a história, e outra efetivamente sociológica.

Em vista desse embate, o problema de pano de fundo é se Weber possui duas concepçóes de Sociologia (como defende Lichtblau) ou se a sua Sociologia passou apenas por um processo de amadurecimento conceitual

\footnotetext{
Doravante, WuG.

7 "Aparato conceitual" ou "arcabouço conceitual" é o léxico de conceitos centrais. Isso significa que, nos textos pós-Guerra, Weber adota conceitos semelhantes para um conjunto de textos.

8 Comumente, em seus textos do início da década de 1910, Weber trata as "ciências culturais" em proximidade com a definição de Rickert, como a economia e a história (LICHTBLAU, 20I5).
} 
sem mudança de concepção (conforme defende Schluchter). De forma particular, o problema de pesquisa se concentra sobre as alteraçóes teóricas e conceituais realizadas por Weber nos textos Kategorien (1913) e Grundbegriffe (1921). Em conformidade com os estudos recentes de Carlos Eduardo Sell $(2016,2018)$, inserimo-nos no esforço de avançar o debate especializado em Weber no Brasil, pois propromo-nos a fortalecer a discussão sobre seus estudos metodológicos.

Em face disso, de maneira geral, objetivamos identificar e discutir as implicaçôes analíticas das alterações conceituais realizadas por Weber nos textos Kategorien (1913) e Grundbegriffe (1921) a fim de compreender o desenvolvimento de sua concepção de Sociologia. Especificamente, intentamos a) situar os escritos de 1913 e 1921 no contexto do processo de redação de $W u G$; b) sistematizar os conceitos centrais do esquema sociológico weberiano tomando como base o esquema macro-micro-macro e c) identificar, comparativamente, as principais alterações terminológicas realizadas por Weber no nível micro e macro de análise sociológica entre 1913 e 1921.

Para tanto, adotamos o procedimento metodológico da pesquisa bibliográfica e a organizamos, em consonância com o Schluchter (2005), em uma dupla interface: 1) análise histórico-sociológica [problemgeschichtliche Untersuchungen] (da história da obra) 2) com intençáo sistemática [in systematischer Absicht konzipiert] (na tentativa de reconstruir os conceitos centrais dos escritos metodológicos a partir do debate contemporâneo micro-macro). Analisamos exegeticamente a estrutura conceitual dos seus textos metodológicos em questão - nomeadamente, os conceitos de ação social, relação social, organizações e ordem social - à vista do debate contemporâneo micro-macro. Por essa razão, não trataremos dos aspectos "epistemológicos" da questáo, quer dizer, dos aspectos que se referem à dimensão formal da análise sociológica em sua dimensão ou base filosófica, o que inclui temáticas como compreensão, explicação, sentido, adequação causal, entre outras. Como a lista acima indica, o esquema micro-macro deslocará nossa atenção para os aspectos substantivos do esquema metodológico de Weber, ou seja, para a sequência conceitual ação/relação/ordem/organização. 
Com isso, ao prescrutinar exegeticamente (e em níveis) os fenômenos emergentes da ação, pretendemos contribuir com a teoria sociológica weberiana. Inserindo-nos na querela internacional de debates atuais sobre Max Weber, sobretudo aquela motivada pela reorganização crítica dos escritos weberianos desenvolvida pela Max Weber-Gesamtausgabe (que póe em evidência as permanências e as transformaçóes teórico-conceituais de Weber), pretendemos contribuir, esmerar e atualizar o debate que vem sendo feito no Brasil.

Este trabalho trata de descortinar, portanto, a concepção de Sociologia de Max Weber, especialmente em seus aspectos metodológicos, a fim de aprofundar o debate em torno da questão se podemos encontrar uma Sociologia reformulada (conforme defende Schluchter) ou duas Sociologias distintas (segundo defesa de Lichtblau). Afinal, as modificaçôes terminológicas realizadas por Weber podem implicar mudanças e/ou rupturas epistemológicas e metodológicas? Levando em consideração esta pergunta-chave, mas abandonando sua formulação dicotômica e excludente, e ainda sem a pretensão de uma resposta exaustiva e taxativa, pretendemos antes levantar aportes que nos permitam uma aproximação à questáo, o que, por sinal, nos leva a dirigir questionamentos para as duas perspectivas. Trata-se, portanto, de acompanhar a reflexão e o amadurecimento do método sociológico de Weber enquanto um processo, mostrando a partir de que pontos e problemas tal processo emerge, seja em termos de continuidade, seja em termos aprofundamento, seja ainda em termos de deslocamentos e reformulaçóes. É tomando em conta essa indagação que pretendemos aprimorar nossa compreensão da formulação da sociologia weberiana em seus aspectos conceituais centrais e axiais.

\section{História da obra}

O trabalho de reorganização dos escritos weberianos realizado pela Max Weber-Gesamtausgabe ( $M W G$ ) há largos anos trouxe à tona, novamente, a discussáo sobre a história dos escritos de Weber e suas respectivas alocaçôes no conjunto de sua obra. Vejamos como esse empreendimento nos ajuda a entender a relação entre Kategorien (1913) e Grundbegriffe (1921). 


\section{I Über einige Kategorien der verstehenden Soziologie (1913)}

Em 1914 havia um debate agendado, na Associação de Política Social, sobre o papel dos juízos de valor nas Ciências Econômicas e Sociais. De acordo com Schluchter (2012), em carta endereçada a Heinrich Rickert, Weber externaliza o desejo de publicar o seu ensaio sobre a Sociologia Compreensiva como uma ciência empírica da ação antes do evento da Associação de Política Social. Por isso, em setembro de 1913, antes do evento, Weber enviou o ensaio para a Revista Logos - o qual foi publicado no volume IV.

Todavia, conforme aponta Schluchter (2014), o texto Kategorien (1913) provavelmente foi concebido como uma introdução para $W u G$. Isso por dois motivos. Em primeiro lugar, Weber esclarece na nota preliminar de Kategorien (1913) que a segunda parte do ensaio (as duas partes de Kategorien e suas respectivas características estão organizadas no Quadro 1) foi escrita há algum tempo e que deveria servir de subsídios para o Manual que seria lançado em breve. Em segundo lugar, a publicação do Manual estava prevista para 1914, e, portanto, Weber deveria enviar o seu texto logo. Mas, ainda assim, o autor optou por publicar o seu ensaio fora do Manual.

Quadro I - Partes de Kategorien (1913) e suas respectivas características

\begin{tabular}{|l|l|l|}
\hline $\begin{array}{l}\text { Partes } \\
\text { Características }\end{array}$ & Primeira parte & Segunda parte \\
\hline \multirow{2}{*}{ Seções } & $\begin{array}{l}\text { I - O sentido da "Sociologia } \\
\text { Compreensiva". } \\
\text { II - A sua relação com a } \\
\text { "psicologia". } \\
\text { III - A sua relação com a } \\
\text { "dogmática". }\end{array}$ & $\begin{array}{l}\text { IV - O "agir comunitário". } \\
\text { V - "Socialização" e "agir } \\
\text { societário". } \\
\text { VI - O "consenso". } \\
\text { VII - "Instituto" e "associação". }\end{array}$ \\
\hline \multirow{2}{*}{ Tema geral } & $\begin{array}{l}\text { Sociologia Compreensiva como } \\
\text { uma ciência da ação }\end{array}$ & $\begin{array}{l}\text { Fundamentação metodológica para } \\
\text { pesquisas substantivas }\end{array}$ \\
\hline \multirow{2}{*}{ Debate central } & $\begin{array}{l}\text { Método da Sociologia } \\
\text { Compreensiva }\end{array}$ & $\begin{array}{l}\text { Categorias da Sociologia } \\
\text { Compreensiva: ação comunitária, } \\
\text { ação societária, ação por acordo, } \\
\text { ordem e organização. }\end{array}$ \\
\hline \multirow{2}{*}{ Período de redação } & Verão de I9I3 & Entre I909 e I9I0 \\
\cline { 3 - 3 } & ou em I9I2 \\
\hline
\end{tabular}

Fonte: Adaptado de Schluchter (20/4). 
A primeira parte do ensaio foi escrita no verão de 1913, e, por isso, possui terminologias semelhantes às do capítulo sobre religião de $W u G-$ que também foi escrito no verão do mesmo ano. Nessa parte, Weber se dedica a elucidar as especificidades da Sociologia Compreensiva. Tal Sociologia não se fundamenta nem em bases psicológicas nem em bases normativas; por isso, se distancia das ciências dogmáticas. Antes, ela atenta para o sentido subjetivamente visado da ação.

Já o período de escrita da segunda parte do ensaio é alvo de controvérsias. Numa carta enviada a Rickert, em 05 de setembro de 1913, Weber fala que a segunda parte do texto estava finalizada há 3/4 anos. Isso é passível de duas interpretaçóes: pode-se inferir tanto que "3/4" são três ou quatro anos quanto que " $3 / 4$ " são três quartos de um ano (ou seja, nove meses). Ainda que não tenhamos exatidão da data de escrita, sabemos que a segunda parte do texto é anterior à primeira (SCHLUCHTER, 2014). Ela pode ter sido escrita entre 1909 e 1910 ou em 1912.

É importante discutir a cronologia de redação das duas partes do texto, pois na segunda parte Weber desenvolve o aparato conceitual de análise, e, vale dizer, esse aparato passa a ser empregado nos textos posteriores a 1913. Os textos anteriores à escrita da segunda parte de categorias (como A economia e as ordens) não adotam, por exemplo, as noçóes de ação comunitária, ação societária, ação por acordo, ordem e organização. Percebe-se, com isso, que os textos escritos antes da Primeira Guerra não utilizam o mesmo léxico.

Por mais que Weber tenha desenvolvido um aparato conceitual complexo e robusto, a sua formulação foi alvo de severas críticas. Seu amigo, Hermann Kantorowicz, em carta enviada em dezembro de 1913, afirma que a Sociologia Compreensiva é "incompreensível” (MWG II/8, [19131914], 2003, p. 447). Em vista disso, em 1917, em conversa com o editor Paul Siebeck, Weber manifestou a intenção de produzir uma publicação conjunta dos seus textos sobre metodologia. Tal publicaçáo contaria com uma nova e mais acessível versão do texto de 1913, com artigos publicados no Schmollers Jahrbuch, no Archiv für Soszialwissenschaft und Sozialpolitik e no Verein für Sozialpolitik. Dentre esses textos, estariam a pesquisa sobre os trabalhadores na grande indústria e as observaçóes sobre o juízo de valor (SCHLUCHTER, 2014). 
Apesar da compilação de seus textos metodológicos não ter sido publicada em vida, a nova e mais acessível versáo do texto de 1913 foi lançada postumamente em $W u G$ com o título Soziologische Grundbegriffe. Na nota preliminar dos Grundbegriffe (1921), Weber esclarece que esse não é um assunto inédito de sua obra. Sua intenção com o ensaio era, antes, formular de maneira mais clara e correta o que já havia discutido em 1913. Quando oportuno e necessário, a sua terminologia foi simplificada e modificada (vide seção 1.3).

A estrutura geral de ambos os textos é mantida: há uma parte inicial de discussão metodológica e uma segunda parte de discussão conceitual. Mesmo assim, é possível perguntar-se se os Grundbegriffe (1921) substituem as Kategorien (1913). Schluchter (2014) propóe uma interessante solução para esse impasse: os Grundbegriffe substituem Kategorien do ponto de vista da história da obra, pois eles são um aperfeiçoamento léxico, teórico e metodológico. Mas, do ponto de vista conceitual, não é possível descartar as Kategorien. Elas serviriam de introdução para as contribuiçôes de Weber para a coletânea de economia social, escritas antes da Primeira Guerra.

\subsection{Soziologische Grundbegriffe ( 1921 )}

Em 1998, o Comitê do Programa de Congressos da ISA (International Sociological Association) realizou uma pesquisa de opiniâo com seus membros sobre os dez livros mais influentes para os sociólogos do século XX. Os resultados socializados no Congresso Mundial de Sociologia da ISA, realizado em Montreal, indicaram que Economia e Sociedade [Wirtschaft und Gesellschaft] é considerada pelos próprios sociólogos a obra sociológica mais importante. Seguido de Economia e Sociedade, que recebeu 20,9\% dos votos, estão sucessivamente: A Imaginação Sociológica de Charles Wright Mills (13\%), Teoria Social e Estrutura Social de Robert Merton (11,4\%), A Ética Protestante e o Espirito do Capitalismo de Max Weber (10,3\%) e A Construção Social da Realidade de Peter Berger e Thomas Luckmann (9,9\%).

Apesar de tal notoriedade, o próprio autor de Economia e Sociedade não havia concebido a obra no formato em que ela se encontra disponível hoje. Há quem advogue, inclusive, que a táo famosa Economia e Sociedade, 
especialmente a edição organizada por Winckelmann, não é uma obra coesa e única (TENBRUCK, 1977; SCHLUCHTER, 1998). Antes, ela seria fruto da organização póstuma de Marianne Weber, Melchior Palyi e Johannes Winckelmann. Há outros teóricos que, por outro lado, indicam potenciais da organização realizada pela esposa de Weber e por seu admirador Winckelmann (ORIHARA, 2003). Frente a essas posiçôes tão distintas, é importante elucidar as intenções do próprio Weber, expressas em cartas e outros veículos, ao se dedicar à escrita do Manual de Economia Política.

\subsection{De Handbuch der politschen Ökonomie, a Grundriss der Sozialökonomik, a, por fim, Wirtschaft und Gesellschaft}

De 1882 até a primeira década do século XX, prevaleceu o uso de um único manual de economia política na Alemanha: o Handbuch der politischen Ökonomie de Gustav von Schönberg9. Esse era um extenso livro que servia como um guia da área de economia política. Paul Siebeck, editor da Mohr Siebeck, estava interessado em lançar um atualizado manual que mantivesse o formato e o nome do antigo: cinco volumes divididos em sessóes temáticas, estas que, por sua vez, seriam divididas em capítulos. Em 1909, ao convidar Weber para ser o editor chefe do manual substituto, a Editora já tinha um plano piloto de organização.

O afastamento de Weber da docência há seis anos, suas constantes decepçôes com a política, a sua participação como membro da diretoria da Sociedade Alemã de Sociologia [Deutsche Gesellschaft für Soziologie] e sua renovação psicológica adquirida após as viagens para a Itália e para a Sicília foram forças motrizes para que ele aceitasse tal desafio. Em vista disso, Weber passou parte do ano de 1909 e 1910 a construir um Plano de Distribuição de Matérias [Stoffverteilungsplan] completamente novo. Em tal planejamento prévio, cada capítulo seria destinado a um especialista na área. Para Weber, especificamente, estava reservado o Capítulo IV da Seção III do Livro Primeiro - capítulo intitulado Economia e Sociedade.

9 Gustav von Schönberg foi um economista alemão. Estudou direito e política nas Universidades de Bonn e Berlim. Foi professor da Universidade de Basel, Freiburg e Tübingen. 
Ademais, o título do manual deveria ser modificado para Elementos de Economia Social [Grundriss der Sozialökonomik] ${ }^{10}$ por causa de possíveis problemas jurídicos com o primeiro Handbuch der politischen Ökonomie (PIERUCCI, 2008). O Quadro 2 organiza, com base no sumário prévio de 1910 explicitado por Pierucci (2008, p. 46), os textos previstos para escrita de Weber em 1910:

Quadro 2 - Plano de Distribuição de Matérias de 1910

Livro Primeiro. Economia e ciência econômica [Wirtschaft und Wirtschaftswissenschaft] Seção III. Economia, natureza e sociedade [Wirtschaft, Natur und Gesellschaft]

Cap. $4^{\circ}$. Economia e sociedade [Wirtschaft und Gesellschaft]

a) Economia e direito [Wirtschaft und Recht]

I. Relação de princípio [prinzipielles Verhältnis]

2. Épocas no desenvolvimento da situação hodierna [Epochen der Entwicklung des heutigen Zustands]

b) A economia e os grupos sociais: grupo familiar e comuna; estamentos e classes; Estado [Wirtschaft und soziale Gruppen: Familien- und Gemeindeverband; Stände und Klassen; Staat]

c) Economia e cultura (crítica do materialismo histórico) [Wirtschaft und Kultur (Kritik des historisches Materialismus)]

Fonte: Pierucci (2008, p. 46).

É importante notar que, no Stoffverteilungsplan de 1910, era intitulado "Economia e Sociedade" somente o capítulo de incumbência de Weber. Contudo, inúmeros autores atrasaram a entrega de seus capítulos ou não os entregaram. E isso impossibilitou a publicação no prazo esperado. Foi necessário, portanto, reorganizar completamente o sumário e adiar o lançamento para o verão de 1914 . Nessa nova organização, Weber ficou responsável por uma seção completa, composta de oito capítulos. Segue abaixo o Stoffverteilungsplan de 1914, também sistematizado por Pierucci (2008, p. 47).

10 Doravante, GdS 
Quadro 3 - Plano de Distribuição de Matérias de 1914

\begin{tabular}{l}
\hline Título da Seção C: Economia e Sociedade [Wirtschaft und Gesellschaft] \\
Subtítulo: A economia e as ordens e poderes sociais [Die Wirtschaft und die gesellschaftlichen \\
Ordnungen und Mächte] \\
\hline I. Categorias das ordens sociais [Kategorien der gesellschaftlichen Ordnungen] \\
- Economia e direito em sua relação de princípio [Wirtschaft und Recht in ihrer prinzipiellen \\
Beziehung] \\
- Relações econômicas dos agrupamentos em geral [Wirtschaftlichen Beziehungen der Verbände \\
im allgemeinen] \\
\hline 2. Comunidade doméstica, oikos e empresa [Hausgemeinschaft, Oikos und Betrieb] \\
\hline 3. Associação de vizinhança, clã, comunidade local [Nachbarschaftsverband, Sippe, Gemeinde] \\
\hline 4. Relações comunitárias étnicas [Ethnische Gemeinschaftsbeziehungen] \\
\hline 5. Comunidades religiosas [Religiöse Gemeinschaften] \\
- Condicionantes de classe das religiões [Klassenbedingheit der Religionen] \\
- Grandes religiões e disposição econômica [Kulturreligionen und Wirtschaftsgesinnung] \\
\hline 6. A comunitarização de mercado [Die Marktvergemeinschaftung] \\
\hline 7. A associação política [Der politische Verband] \\
- As condiçães do desenvolvimento do direito. Grupos de status, classes, partidos. A nação [Die \\
Entwicklungsbedingungen des Rechts. Stände, Klassen, Parteien. Die Nation] \\
\hline 8. A dominação [Die Herrschaft] \\
(a) Os três tipos de dominação legítima [Die drei Typen der legitimen Herrschaft] \\
(b) Dominação política e hierocrática [Politische und hierokratische Herrschaft] \\
(c) A dominação não legítima: Tipologia das cidades [Die nichtlegitime Herrschaft: Typologie der \\
Städte] \\
(d) O desenvolvimento do Estado moderno [Die Entwicklung des modernen Staates] \\
(e) Os partidos políticos modernos [Die modernen politischen Parteien] \\
\hline
\end{tabular}

Fonte: Pierucci (2008, p. 47).

É possível destacar que o plano de 1914 se aproxima (mas não é idêntico!) da publicação final da Primeira Parte da 5a edição de $W u G$. Questóes como as ordens sociais, as relaçóes econômicas, as comunidades, as associações, as comunidades religiosas, o mercado, os partidos, as classes e a dominação são discutidas na edição de $W u G$ hoje em circulação em diferentes idiomas. Todavia, a disposição dos textos e os títulos dos capítulos são distintos.

Não foi possível concretizar o novo Plano de Distribuição de Matérias, pois em 1914 eclodiu a Primeira Guerra Mundial. Para além de adiar 
novamente o prazo, foi necessário suspender as atividades acadêmicas. Afinal, Weber foi convocado a assumir o cargo de oficial disciplinar da Comissão dos Hospitais Militares do Corpo de Reserva. O alemão também se dedicou, nesse período, a escrever memorandos sobre a Guerra, realizar debates públicos e escrever artigos políticos para o Frankfurter Zeitung.

Em vista disso, Weber não trabalhou na sua contribuição para o manual entre 1914 e 1917. Seu trabalho foi retomado somente entre 1918 e 1919, agora com nova motivação. Weber se dedicou, ao longo de 1919 e 1920, a revisar e reescrever seus textos para o $G d S$. Seu intuito era o de tornar seus textos mais objetivos e com menos material histórico. A Figura 1 ilustra as diferentes fases de escrita dos textos que compóem a primeira parte de Economia e Sociedade.

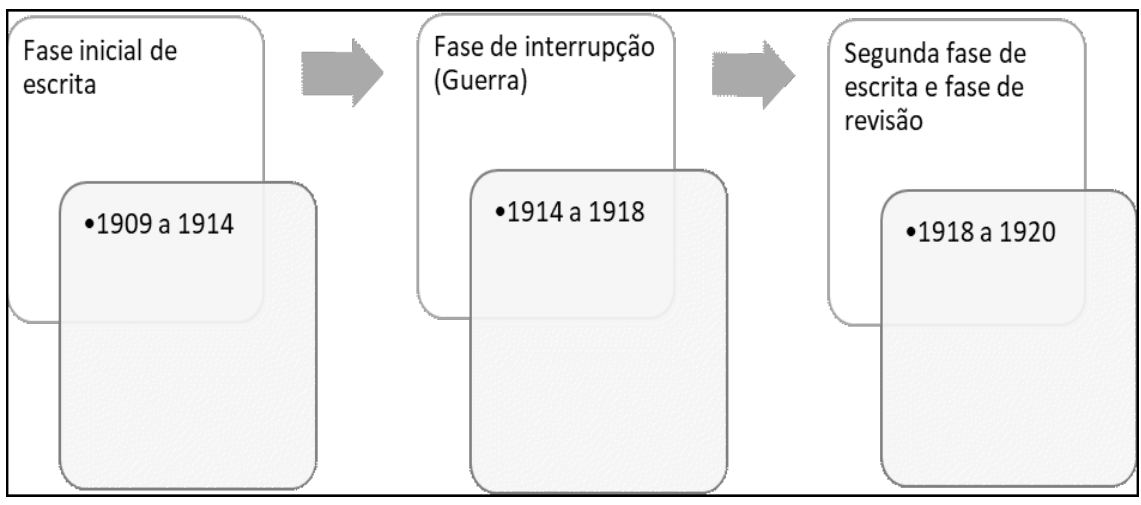

Figura I - Fases de redação dos textos da primeira parte de WuG. Fonte: Adaptada de Mommsen (2000).

De acordo com Lepsius (2012), acabada a Grande Guerra, Paul Siebeck pressionou os autores do $G d S$ pela publicação do manual. Foi então que Weber começou a reorganizar seus textos de forma mais curta e concisa - escrita mais aproximada a de um manual. Ainda, conforme explicita Pierucci (2008, p. 48):

[Weber] partiu para a composição de um texto puramente categorial de Sociologia, muito mais formal e sistemático do que histórico-substantivo, bem o contrário do que havia feito 
no primeiro manuscrito interrompido de 1914, considerado "mais sociológico". Ele parecia de tal modo decidido a uma formulação radical do aparato conceitual que empregara nas etapas anteriores de sua produção, de tal forma determinado a colocar numa formulação rigorosamente sistemática de um novo dispositivo de conceitos sociológicos que, já no ano seguinte [1920], estava pronto o novo trabalho.

Vale, aqui, fazer uma explicitação. Mommsen (2000) faz uma interessante proposição ao afirmar que desde os cursos da década de 1890 Weber vinha desenvolvendo uma nova abordagem para o estudo da realidade social. Em especial, uma abordagem que compreendesse as formas econômicas e os vários tipos de comunidade por meio da combinação do tipo ideal, da análise histórica-universal e da compreensão dos fenômenos no tempo e no espaço: "Great article 'Wirtschaft, Gesellschaft, Recht und [Staat]' was going to become 'the best sistematic piece' that he had written so far. Half a year later he suggested to Siebeck that he be given more space for his contribution, which he now for the first time called "my Sociology" (MOMMSEN, 2000, p. 376)"'.

Os estudos que estavam na gráfica, os "autorizados" por Weber, tinham esta ordem: Capítulo I - Conceitos Sociológicos fundamentais, Capítulo II - Categorias Sociológicas fundamentais da ação econômica, Capítulo III - Tipos de Dominação e Capítulo IV - Estamentos e Classes. Esses foram os capítulos que, de acordo com Pierucci (2008), passaram a compor a primeira parte do livro posteriormente chamado de $W u G$.

Infelizmente, Weber faleceu em meio à (re) organização de seus textos para o manual. Concomitantemente a escrita do manual Weber se dedicou a outros empreendimentos, que também ficaram incompletos, como é o caso dos Ensaios Reunidos de Sociologia da Religião [Gesammelte Aufsätze zur Religionssoziologie $]^{12}$. A diferença entre os demais estudos e $W u G$ é que Marianne Weber, Melchior Palyi e Johannes Winckelmann se dedicaram a tornar $W u G$ uma obra coerente.

II “Um ótimo artigo 'Economia, Sociedade, Direito e Estado' se tornaria ‘a melhor peça sistemática' que ele havia escrito até agora [meados da segunda década do século XX]. Meio ano depois, ele sugeriu a Siebeck que lhe dessem mais espaço para sua contribuição, que ele agora pela primeira vez chamou de "minha sociologia'" (MOMMSEN, 2000, p. 376, tradução do autor).

12 Doravante, GARS. 
Além dos textos citados anteriormente e que foram autorizados por Weber, que compuseram a primeira parte da obra, há os manuscritos encontrados em uma pilha sobre a sua mesa (MOMMSEN, 2000). Inúmeras foram as dificuldades para organizar todo o material do espólio. Conforme aponta Marianne Weber (1921) no prefácio à primeira edição: "Para a estruturação de todo o material não existiu plano algum. $\mathrm{O}$ plano original, esboçado nas páginas X e XI do primeiro volume de $G d S$ ofereceu alguns pontos de referência, mas em aspectos substanciais já fora abandonado. Por isso, a ordem dos capítulos tinha de ser decidida pela organizadora do texto e seu colaborador".

\section{Weber na perspectiva micro-macro}

Feita a discussão histórico-textual, então, passamos para a discussão analítica retomando a relação entre Kategorien e Grudbegriffe a partir da distinção contemporânea "micro-macro" de análise sociológica. As disputas teóricas acerca do que Weber quis dizer dominaram o cenário da discussão especializada até o final do século XX. Discussóes recentes, majoritariamente realizadas por pesquisadores da Universidade de Heidelberg, sinalizam novos impulsos para a interpretação da obra weberiana. Para além de compreender o que Weber quis dizer, esses estudiosos se perguntam sobre o que é possível fazer com sua teoria no atual curso da Sociologia. Em outras palavras, esses pesquisadores se propóem a atualizar o pensamento de Weber de acordo com as discussóes contemporâneas. Nas palavras de Sell (2014a, p. 37):

De um lado nota-se o esforço de desfossilizar a obra de Max Weber que, na condição de clássico, fica reduzido à condição de autor canônico e rotinizado na formação de cientistas sociais e fonte de citações ou empréstimos conceituais topicamente orientados em função de pesquisas específicas e localizadas, mas não uma fonte de problemas teóricos e empíricos que mobilizam a discussão científica. Por outro, este esforço de atualização, mais do que sistematizações teóricas amplas, tem se preocupado com o aprofundamento de áreas específicas da investigação social.

Esses intérpretes - como Gert Albert, Agathe Bienfait, Steffen Sigmund, Claus Wendt, Thomas Schwinn e, inclusive, Wolfgang Schluchter - centram a discussão nos fundamentos epistemológicos e metodológicos 
da obra de Weber. Especificamente, eles argumentam em prol da utilidade do método weberiano no quadro corrente da Sociologia por meio de uma adequação de sua discussão ao debate contemporâneo. Especialmente os estudos de Gert Albert (2016) ${ }^{13}$ sobre a distinção contemporânea micro-macro na obra de Weber servirão de referência teórica a para o desenvolvimento da dissertação, tal como explicamos na seção 3.2.

Gert Albert (2016), especificamente, questiona se efetivamente há uma primazia do plano micro sobre o macro nos textos "empíricos" (ou históricos) de Weber. Consoante à abordagem inaugural que David McClelland (1961) concede à Ética Protestante e o Espirito do Capitalismo $(P E)$, Albert (2016) defende que há na obra weberiana o modelo analítico "macro-micro-macro". O espírito do capitalismo, uma forma de orientação econômica da ação, é influenciado pela ética religiosa do protestantismo ascético. O caráter secular do espírito do capitalismo possui afinidades com o típico homem econômico moderno. Percebe-se, com isso, que o modelo analítico da $P E$ confere igual peso à ação e à estrutura social. A Figura 2 organiza os níveis analíticos de $P E$.

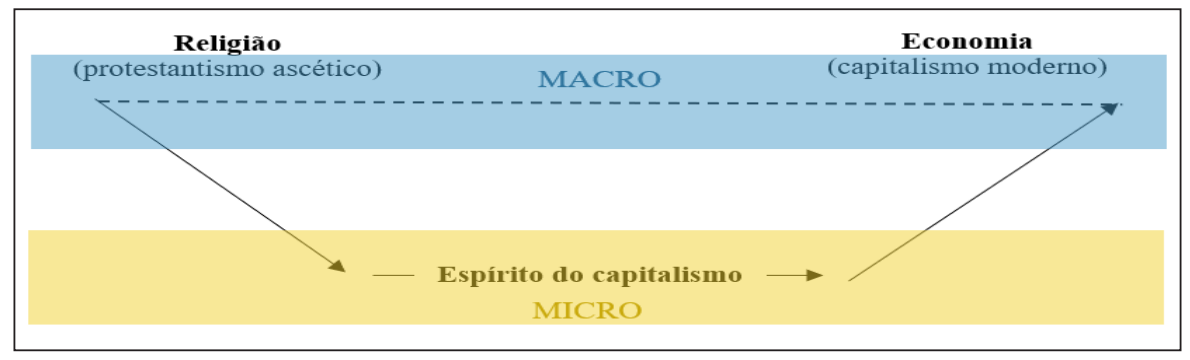

Figura 2 - Níveis analíticos de A ética protestante Fonte: Adaptada de McClelland (1961, p. 47).

13 Para Albert (2016), o desenvolvimento de um paradigma weberiano exige a discussão dos problemas ontológicos, metodológicos e empíricos. Por isso, o autor sugere que um paradigma weberiano pode ser designado como um holismo metodológico moderado. Isso é, um modelo micro-macro de explicação no qual se admite o nível micro agindo sobre o macro e vice-versa. Contudo, a dependência do nível micro sobre o macro é menor do que o inverso. Sua tese é que, nos textos histórico-empíricos, Weber priorizou a influência do nível macro sobre o nível micro. 
De acordo com o esquema ilustrado acima, não há uma relação causal direta entre os dois fenômenos macro (a religiáo e a cultura). Antes, há um fluxo causal que vai de um fenômeno macro (a religião), a um fenômeno micro (o espírito do capitalismo), e, então, a outro fenômeno macro (a economia). Em vista disso e com base nos estudos históricos de Weber, Albert (2016) propóe reenquadrar a teoria weberiana na discussão contemporânea micro-macro/individualismo-holismo. Para tanto, leva em consideração estes aspectos:

1) A emergência: a influência da estrutura ou independência do plano macro sobre o micro. As teorias da emergência partem do pressuposto de que a explicação dos fenômenos sociais ou dos fenômenos do "espírito" remonta aos elementos materiais. Isso porque somente os elementos materiais podem gerar propriedades emergentes. Essa emergência pode ser de dois tipos:

a. Forte: propriedades explicativas irredutíveis ao nível micro.

b. Fraca: propriedades explicativas redutíveis ao nível micro.

2) A causalidade dos níveis: se a abordagem admite causalidade ascendente (micro-determinaçáo) ou se também admite a causalidade descendente (macrodeterminação).

O Quadro 4 sistematiza os tipos de abordagem (individualismo moderado, individualismo radical, holismo moderado ${ }^{14}$ e o holismo radical) segundo suas emergências e causalidades.

I4 De acordo com Gert Albert (2016), o "individualismo insitucional” desenvolvido por Joseph Agassi tem como alicerce a teoria weberiana. Essa posição metodológica é uma tentativa de unir o individualismo metodológico ao holismo metodológico. Com base nessa abordagem é possível fazer em um "holismo moderado" que não recorre à macrossociologia radical. 


\section{Quadro 4 - Posições metodológicas e suas características}

\begin{tabular}{|c|c|c|c|c|}
\cline { 2 - 5 } \multicolumn{1}{c|}{} & \multicolumn{2}{c|}{ Individualismo } & \multicolumn{2}{c|}{ Holismo } \\
\cline { 2 - 5 } \multicolumn{1}{c|}{} & $\begin{array}{c}\text { Moderado } \\
\text { (micro-macro) }\end{array}$ & $\begin{array}{c}\text { Radical } \\
\text { (micro-micro) }\end{array}$ & $\begin{array}{c}\text { Moderado } \\
\text { (macro-micro) }\end{array}$ & $\begin{array}{c}\text { Radical } \\
\text { (macro- } \\
\text { macro) }\end{array}$ \\
\hline Emergência & Fraco & Inexistente & Fraco e forte & Forte \\
\hline Causalidade & $\begin{array}{c}\text { Somente macro- } \\
\text { micro, micro-macro } \\
\text { e micro-micro }\end{array}$ & Somente micro & $\begin{array}{c}\text { Somente macro- } \\
\text { micro, micro-macro } \\
\text { e macro-macro }\end{array}$ & Somente macro \\
\hline
\end{tabular}

Fonte: Adaptado de Albert (20/6).

Também Wolfgang Schluchter (2005) desenvolveu uma análise de múltiplos níveis de $P E$. A partir dos insights iniciais de David McClelland (1961) sobre os níveis de análise da PE, Schluchter criou um modelo complexificado. $\mathrm{O}$ autor entende que a ética religiosa do protestantismo ascético levou ao desenvolvimento do espírito do capitalismo, ainda que não diretamente. A Figura 3 ilustra o seu esquema:

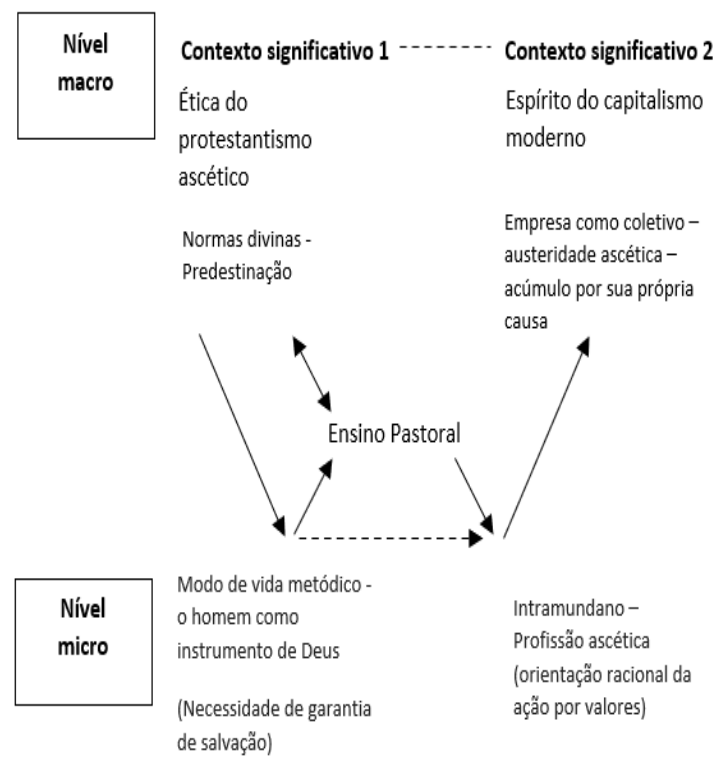

Figura 3 - Modelo de análise de Schluchter Fonte: Schluchter (2005). 
Consoante à defesa de Schluchter (2005), Weber examina apenas um lado da relação causal: a influência de uma cultura religiosa sobre a mentalidade econômica [Wirtschaftsgesinnung] e sua consequente formação de uma organização religiosa. Mas há, nesse trâmite, uma etapa intermeditária não discutida claramente, mas também não suprimida: o ajuste paulatino dos padróes de interpretação religiosos subjetivos sobre a crença na necessidade de garantia da salvação. Somente a partir disso é possível o surgimento do "espírito" do capitalismo moderno. É justamente pela impossibilidade de reduzir os padrôes de interpretação subjetivos à ética protestante ascética que Schluchter defende Weber como um individualista moderado.

Gert Albert, sob outra perspectiva, inicialmente, no artigo Holismo $\mathrm{Me}$ todológico Moderado: uma interpretação weberiana do modelo macro-micro-macro de 2016, desenvolveu uma interpretação holista-moderada do modelo macro-micro-macro da obra de Weber. Isso porque, no holismo moderado, admite-se tanto a existência de fenômenos emergentes fortes (causalidade descendente) quanto fracos (causalidade ascendente). Dito de outra forma, o holismo moderado admite causalidade do nível macro sobre o micro e do nível micro sobre o macro desde que elas sejam mediadas pela ação humana.

Weber se afasta do individualismo moderado, argumenta Albert (2016), porque ele admite a influência forte do nível macro sobre o micro. $\mathrm{O}$ exemplo é a influência da conduta ética do protestantismo ascético sobre o desenvolvimento do espírito capitalista. Ou como, de maneira geral, há influência das normas e instituiçốes sobre a ação dos atores. Essa é uma posição antirreducionista, pois não admite a sobredeterminação do nível macro sobre o nível micro nem a sobredeterminação do nível micro sobre o macro.

Com base na posição antirreducionista de Weber, Albert (2016) sustenta a fundação de um paradigma de múltiplos princípios de ação (macro-micro-macro). A ação pode ser inicialmente motivada, moldada ou orientada por uma macroestrutura social (macro-micro). Logo após, essa mesma ação passa por um processo de contato com as demais características dos indivíduos (micro-micro). Por fim, há um processo de conexão das açóes individuais às regras institucionais (micro-macro).

Mas essa inovadora interpretação dos escritos weberianos não tardou a receber críticas. Dentre elas, destacamos as que argumentam em prol da impossibilidade de encontrar macrodeterminaçóes na sociologia de Weber 
(ESSER, 2006). De acordo com Carlos Sell (2014a, p. 46), após tais críticas Albert reviu a sua posição e:

[...] simplesmente transcende a divisão e passa a advogar que a posição metodológica weberiana pode ser situada como uma terceira via que evita tanto a tendência reducionista de privilegiar o polo da ação sobre o polo da estrutura (atomismo) ou, ao contrário, o polo da estrutura sobre o plano do agente (coletivismo). Na senda de autores como Pierre Bourdieu, Habermas ou, para empregar aqui a já usual expressão de Anthony Giddens, Weber seria, avant la lettre, um teórico da "dualidade da estrutura”. Nem só as estruturas (primeira via), nem somente a agência (segunda via), o fato é que Weber nos abre um caminho para uma terceira via que integra as duas abordagens concorrentes.

Ainda que Albert tenha mudado a sua posição, importa, para este estudo, o seu esforço de discutir contemporaneamente a teoria weberiana. Em especial, interessa-nos a sua tentativa de enquadrar o debate metodológico de Weber no debate dos níveis de análise micro-macro. Ainda que a distinção micro-macro tenha origem na teoria da escolha racional, a utilização dessa dicotomia como um esquema meta-teórico não implica, necessariamente, a opção teórica da escolha racional (SELL; PAULA JUNIOR, 2016). É possível utilizar a distinção micro-macro como um esquema auxiliar de níveis de análise. E é justamente esse esquema de níveis de análise o que nos interessa para o desenvolvimento desta pesquisa.

Objetivamente, essa divisão em níveis de análise (nível micro e nível macro) nos será útil para organizar a investigação dos conceitos centrais da metodologia weberiana. Schluchter (2016) propóe, com base no enquadramento metodológico da teoria weberiana em níveis feito por Albert (2016), ordenar os conceitos desta forma: nível micro (ação social), micro macro (relação, ordem e organização).

\section{$4 \mathrm{~A}$ estrutura conceitual}

De Kategorien para Grundbegriffe Weber manteve uma "espinha dorsal”: ação-relação-ordem-organização. As terminologias, entretanto, foram amplamente alteradas de 1913 para 1921 (SCHLUCHTER, 2014). $\mathrm{Na}$ Figura 4 há a sistematização da estrutura conceitual das noções fundamentais do léxico weberiano de Kategorien partindo de ação comunitária e chegando ao nível da ordem estatuída. Na Figura 5, por sua vez, há a estrutura conceitual de Grundbegriffe. Ao comparar a estrutura conceitual da Figura 4 
(Kategorien) com a da Figura 5 (Grundbegriffe), facilmente identifica-se a complexificaçăo, a ampliação, o aprofundamento e o aprimoramento da tipologia.

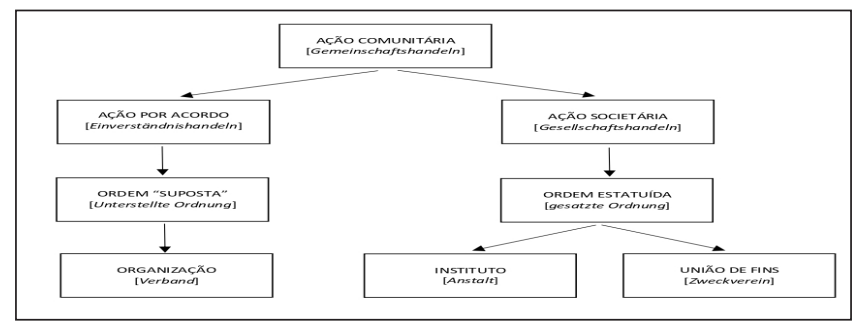

Figura 4 - Estrutura conceitual de Kategorien

Fonte: Adaptada de Schluchter (20/6).

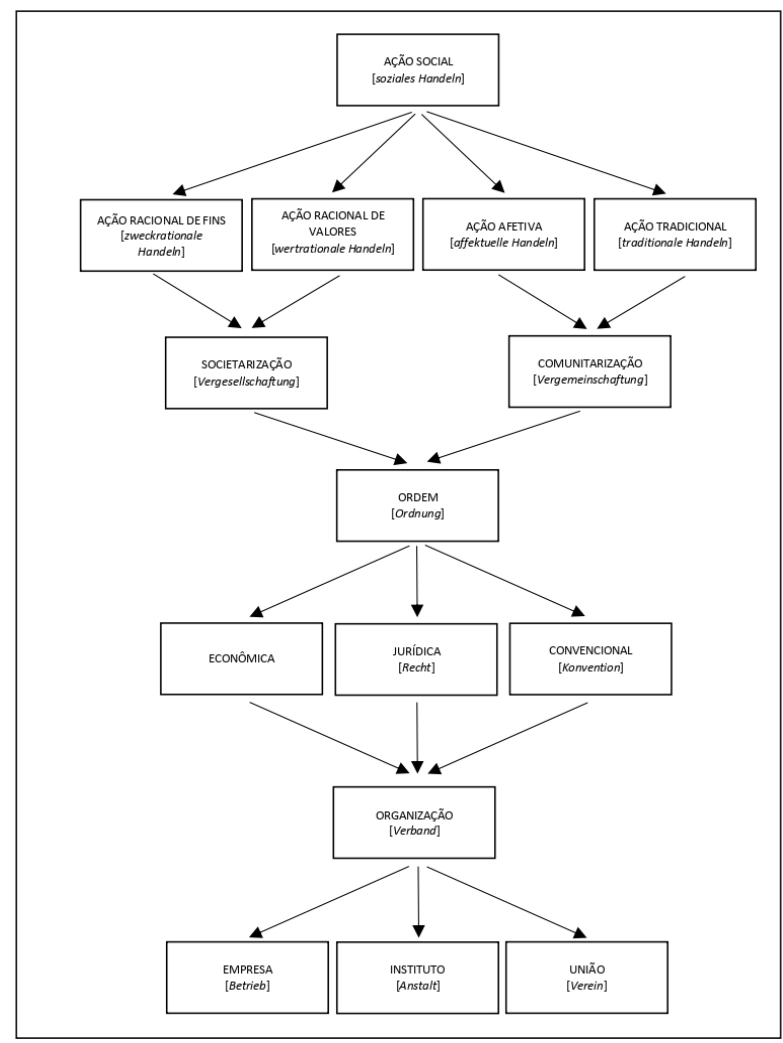

Figura 5 - Estrutura conceitual de Grundbegriffe Fonte: Adaptada de Schluchter (20/6). 
Tomando o esquema micro-macro como referência analítica, colocaremos em destaque as continuidades, os deslocamentos e as transformaçôes no interior do sistema de pensamento do método weberiano. Trata-se de identificar os conceitos que permaneceram, se transformaram ou caíram em desuso em cada nível de análise.

\section{I Transformações no plano microssociológico}

No plano microssociológico, Weber (1921) substituiu a noção de ação comunitária [Gemeinschaftshandeln] pelo conceito de ação social [soziales Handeln]. Ainda que algumas características do "núcleo duro" do conceito tenham permanecido - especificamente a ideia de que a ação em contexto social é um comportamento que se refere, em seu sentido subjetivamente visado, pela expectativa do comportamento alheio - Weber (MWG I/23, [1919-1920], 2013, p. 1) acrescenta à ação social de 1921 a referência à expectativa do comportamento alheio também no nível objetivo do curso externo da ação. No texto anterior, por outro lado, em nível externo/objetivo a ação estava sob a égide da probabilidade calculada de êxito (a possibilidade objetiva [objective Möglichkeit]). Quer dizer, em seu curso externo a ação assenta-se no cálculo do sucesso e êxito próprios com vistas ao "tipo de racionalidade com referência ao correto" [Typus der Richtigkeitsrationalität], ou somente "tipo correto" ${ }^{15}$.

Em Grundbegriffe há um modelo quadritipológico de ação (ação racional com referência a fins, ação racional com referência a valores, ação afetiva e ação tradicional) que não está integralmente contemplado no texto de 1913. A ação social tradicional, por exemplo, é um tipo de ação exclusiva de Grundbegriffe, pois foi somente em 1921 que Weber reconheceu a possibilidade de que açóes fossem rotinizadas, resultantes de estímulos quase automatizadas, que decorressem de hábitos que progressivamente vão se enraizando no agente. A inclusão do elemento da tradição em

15 Em inglês este termo foi traduzido como "objectively correct type" (Graber). Em francês, como "type de justesse" (Freund). Em castellano, "tipo regular" (Etcheverry). E em português e espanhol como "tipo regular" (Wernet) (FANTA, 2015). Optamos por utilizar a tradução "tipo de racionalidade com referência ao que é correto", visto que ela é mais fidedigna ao termo original Typus der Richtigkeitsrationalität, conforme defesa de Daniel Fanta (2015). 
Grundbegriffe - elemento que, aliás, em momento algum foi abordada em Kategorien - indica uma ampliação do leque causalístico das açóes. Algo que consideramos uma peculiaridade do texto de 1921.

Outra mudança importante de Grundbegriffe foi a inclusão de condutas motivadas por afetos e emoçóes no roll das açóes sociais, ou seja, como açôes que, em seus sentidos subjetivamente visados, são tanto referidas a afetos pessoais quanto orientadas por comportamentos alheios. Essa é uma mudança substantiva; afinal, se antes os afetos eram considerados ora comportamentos (na parte "antiga" de 1913) ora simples açôes (na parte "nova” de 1913), em 1921, com a inclusão da orientação pela expectativa do comportamento alheio, as açóes afetivas passaram a ser consideradas açôes sociais.

A característica que aproxima a ação orientada por afetos e a ação racional com referência a fins é, segundo Norkus (2001), a "flexibilidade". A intitulada "flexibilidade" ("flexibilidade" entre aspas, porque as mudanças das ações são mais influenciadas pela instabilidade do estado interno do ator do que pelas situaçôes objetivas) refere-se à capacidade adaptativa de ambas as açôes: a ação afetiva, devido à transformação dos afetos de acordo com a transmutação das realidades objetivas, e a ação de fins, em razão do ajuste dos meios para alcançar determinados fins.

Há uma característica desse último tipo de ação (ação racional com referência a fins) que o coloca como o suprassumo do modelo weberiano: o ajuste entre expectativas e objetivos. O grau máximo de racionalidade é encontrado nesse tipo de ação devido à equivalência entre os fins da ação e as expectativas conscientes. É esse o modelo que orienta seu curso externo pela expectativa de determinados comportamentos de outros agentes e que, a partir disso, organiza taticamente os meios de sua ação a fim de alcançar o êxito. Por isso, esse tipo de ação pode ser utilizado como parâmetro de comparação com os demais tipos de ação "menos racionalizados" - ou nas palavras de Hartmut Esser "tipos de anomalias da ação de fins”, "nomalias de racionalidade". Por isso, é possível afirmar que há em Weber - em consonância com o que Schluchter $(2011,2014)$ e Jens Greve (2014) propóem - um racionalismo heurístico que privilegia a investigaçáo sociológica por intermédio da ação racional de fins. 
Contudo, é importante notar que, ainda que a ação racional de fins seja utilizada para fins metodológicos como um tipo objetivamente correto passível de comparação em 1913, no texto de 1921 Weber a inclui como parte de seu arquétipo. Embora na parte antiga isso fique sublimado, pois Weber trata a ação de fins como um comportamento orientado por fins e referido a expectativa do comportamento alheio, essa é uma novidade de Grundbegriffe. É somente no texto maduro que Weber concebe a ação de fins como uma efetiva ação social.

Se em Kategorien Weber nos passa a impressão de que a ação de fins seria a única forma racional de ação, em Grundbegriffe esse leque é ampliado a ponto de estabelecer uma inovação metodológica importante. Em 1921 Weber desiste da "racionalidade objetivamente correta" e adota, além da racionalidade de fins, a racionalidade valorativa. Com isso, ele passa a considerar os valores como motivadores de açóes racionais - algo que, aliás, nas duas partes de Kategorien eram tratados somente como comportamentos internos - pois eles estão organizados em função da crença subjetiva em um determinado valor (por exemplo, o dever ético, estético ou religioso). Assim, os dois tipos de ação racional de Grundbegriffe (ação de fins e de valores) são tratados em igual nível de racionalidade.

Em síntese, são duas as diferenças fundamentais e marcantes entre a tipologia anterior (1913) e a tipologia madura (1921):

1. A mudança na aceitação da análise de açôes não racionais. Em Grundbegriffe Weber admite a análise intelectual, tanto de açôes racionais quanto de açóes afetivas e tradicionais;

2. A inclusão de um segundo tipo de ação racional (a de valores). Em Grundbegriffe Weber equivale metodologicamente os dois tipos de ação racional: a ação de fins e a de valores. Somente para fins de conveniência metodológica, a Sociologia Compreensiva é "racionalista".

\subsection{Transformações no plano macrossociológico}

No plano macrossociológico de Kategorien Weber apresentou alguns insights sobre açóes orientadas pela expectativa de comportamento de outras pessoas; mas. não desenvolveu uma teoria sistemática das relaçóes 
sociais. Nesse texto, ele sustenta a ideia de que as relaçóes resultam de açôes reciprocamente orientadas por um conteúdo de significado que está além do sentido das açôes individuais (MWG I/12, [1908-1917], 2018. p. 410). Com isso ele deixa evidente que, quando açóes individuais originam linhas e sentidos mais amplos, elas se orientam por um conteúdo de sentido novo e sensivelmente distinto do conteúdo da ação individual - sentido esse que serve de referência para uma pluralidade de agentes. Há, portanto, dois conteúdos de sentido no interior de uma relação social: o conteúdo de sentido próprio da relação social e o conteúdo de sentido específico de cada ação social que a compóe.

Mas foi somente em Grundbegriffe que Weber inseriu a noção de ajuste [einstellen], o que o permitiu tratar a relação social como comportamentos reciprocamente referidos que, além de orientarem-se uns pelos outros, se "coordenam"16 mutuamente. Isso indica que, mesmo que seus planos de ação sejam distintos, no nível da relação social os atores organizam suas açôes em referência aos outros agentes, adequando-as mutuamente. Em outras palavras, na relação social de 1921, há o rearranjo mútuo de ações sociais e de seus respectivos significados em função de um conteúdo sentido específico. Em termos contemporâneos, os comportamentos mutuamente referidos e ajustados por um conteúdo de sentido comum são chamados de "açóes coordenadas" (SCHLUCHTER, 2014). Há na mudança da ação social (de 1921) para a relação social, portanto, uma transição da "orientação" para a "coordenação".

Em termos tipológicos, percebemos que as mudanças de 1913 para 1921 não são menos substanciais do que as mudanças no nível das açóes. Como em Kategorien não há uma formulação explícita e sistemática como há em Grundbegriffe - do conceito de relação social, os elementos que mediam a ação comunitária (nível micro) e as ordens sociais (nível macro) são a ação por acordo [Einverständnishandeln] e a ação societária [Gesellschaftshandeln]. Por isso, tomamos a liberdade de chamar a Einverständnishandeln e a Gesellschaftshandeln de 1913 como "protoformas de relaçóes sociais”, conforme sistematizado no Quadro 5.

I6 Foi Schluchter (2014) quem atentou para o fenômeno da coordenação da ação em Grundbegriffe. A relação social é, para esse intérprete, um fenômeno emergente da ação que forma padrões complexos de ação a partir de unidades de sentido mais simples. 
Quadro 5 - De ação (1913) para relação social (1921)

\begin{tabular}{|cc|}
\hline 1913 & $192 \mathbf{1}$ \\
\hline Plano microssociológico & Plano macrossociológico \\
\hline Ação por acordo & Comunitarização \\
[Einverständnishandeln] & [Vergemeinschaftung] \\
\hline Ação societária & Societarização \\
[Gesellschaftshandeln] & [Vergesellschaftung] \\
\hline
\end{tabular}

Fonte: Elaborado pela autora (2020).

A Einverständnishandeln de 1913 trata-se de uma ação comunitária que se refere a uma ordem tacitamente compreendida. Quer dizer, embora não haja uma ordem formalmente instituída, as açôes por acordo funcionam "como se" ela existisse. Também na comunitarização [Vergemeinschaftung] de 1921, conceito que parece ser substituto da Einverständnishandeln, o elemento do conhecimento mútuo fica eviden$t^{17}$. Essa é, aliás, a característica distinta dos tipos "comunitários" de Weber. Mas é necessário esclarecer que em Grundbegriffe há uma novidade: Weber inclui a vinculação afetiva, que sequer foi citada na seção 6 de Kategorien. Comunitarizaçóes são relaçóes por meio das quais as pessoas orientam mutuamente seus comportamentos em função do sentimento de pertencimento ao grupo.

A ação societária [Gesellschaftshandeln] de 1913, diferentemente da ação por acordo, orienta-se por um estatuto formalizado, quer dizer, uma ordem estatuída [gesatzte Ordnung] de forma racional referente a fins.

17 Duas notas sobre a ação por acordo [Einverständnishandeln], tipo que desapareceu o arquétipo de Grundbegri$f f e$, são importantes. Ainda que esse conceito tenha sido "esquecido" por Weber, há autores contemporâneos dispostos a revelar seu valor heurístico ou mesmo instrumentalizá-lo em seus próprios arcabouços conceituais. Exemplo do primeiro caso é Schmid (2008). Ele advoga pela tese de que a ação por acordo é a categoria capaz de salvar Weber de uma metodologia que intenta integrar a ação normativa e ação instrumental no mesmo modelo. É na ação por acordo que se pode encontrar uma teoria da intencionalidade coletiva capaz de unir tanto a normatividade social (disposta no acordo implícito) quanto a instrumentalidade das ações (disposta na organização objetiva da ação com a finalidade de fazer cumprir o acordo). É a ação por acordo a que cria interdependência entre os agentes, pois ela interrelaciona as intenções coletivas formuladas no acordo normativo implícito. Exemplo do segundo caso é a teoria da ação comunicativa de Habermas (1999). Habermas desenvolveu um modelo de ator competente linguisticamente que possui bases na "versão não oficial" da teoria da ação de Max Weber. É em Kategorien que, sob essa perspectiva, Weber formula a ideia de que ações podem ser coordenadas por um acordo normativo de pouca institucionalização que permite maior discussão e entendimento. 
Na societarização de 1921, com a incorporação do ajuste dos interesses pessoais, a noção de "sociedade" ganhou nova roupagem. Enquanto a ação societária admite somente açóes puramente racionais com relação a seus fins, a comunitarização admite, além de açóes de fins, açóes racionais de valores. Por isso, no caso da societarização, é possível que o conteúdo de sentido das ações individuais mutuamente se ajuste em função da crença racional em um compromisso próprio.

$\mathrm{O}$ aprofundamento do conceito de relação social, em Grundbegriffe, possibilitou a Weber desenvolver uma teoria sistemática das organizações sociais. Isso porque em 1921 ele passou a conceituar a organização [Verband] como um tipo complexificado de relação social: uma relação "fechada para fora”, isso é, uma relação que possui regulamentação de ingresso de novos membros (MWG I/23, [1919-1920], 2013, p. 35). O termo organização [Verband], em Kategorien, possuía outro sentido: referia-se às formaçóes sociais baseadas em acordos simples, tácitos, não regulamentados, onde vigorava a ação por acordo (MWG I/12, [1908-1917], 2018. p. 433). No texto maduro, por outro lado, a noção de organização se tornou o centro das relaçóes fechadas. Com isso, passou a abarcar todas as relaçóes sociais que regulamentam o ingresso de novos membros das relaçóes de comunitarização e societarização, conforme sistematizado no Quadro 6.

Quadro 6 - Mudanças na teoria das organizações

\begin{tabular}{|cc|}
\hline Plano macrossociológico & Plano macrossociológico \\
\hline Organização & Organização \\
{$[$ Verband] } & {$[$ Verband] } \\
\hline Instituto & Instituto \\
{$[$ Anstalt] } & {$[$ Anstalt] } \\
\hline União de fins & União \\
[Zweckverein] & {$[$ Verein] } \\
\hline Não há* & Empresa \\
& {$[$ Betrieb] } \\
\hline
\end{tabular}

Fonte: Elaborado pela autora (2020).

A união de fins [Zweckverein] de 1913 - conceituada como "ein Gesellschaftshandeln mit einer zweckrational von allen Beteiligten vereinbarten 
Ordnung” (MWG I/12, [1908-1917], 2018. p. 412)18 - desapareceu conceitualmente em Grundbegriffe. Porém, muitas de suas características permaneceram na noção de união [Verein] de Grundbegriffe: como a existência de um estatuto pressuposto e a associação voluntária. Mas é importante notar que a inserção do elemento "planejamento prévio" no conceito de união [Verein] de 1921 o elevou a um maior grau de organização interna. Por isso, tendo em vista as instâncias administrativas, a uniâo [Verein] pode ser compreendida como uma formaçáo social altamente regulamentada.

Também o conceito de instituto [Anstalt] de 1913 - comunidade na qual a participação é obrigatória (isso é, independentemente da vontade do imputado, em oposiçáo à uniáo de fins), o regulamento racional criado por todos os indivíduos é formalmente estabelecido e há um aparato coercitivo (MWG I/12, [1908-1917], 2018. p. 432) - manteve suas características em 1921. Por fim, ao incluir da ideia de atuação contínua do quadro administrativo, Weber inseriu um conceito inédito em seu arquétipo das organizaçóes: a empresa [Betrieb]. Isso sinalizou uma inovação para a estrutura conceitual de sua Sociologia, pois o possibilitou desenvolver uma noção mais "sociológica" do conceito de Estado. O Estado seria, sob essa perspectiva, uma "empresa com caráter de instituto" [Anstaltsbetrieb]; afinal, concomitantemente, ele é impessoal-racionalista (característica do instituto) e contínuo-adaptável (característica da empresa).

Por fim, chegando à última instância do nível macrossociológico da teoria weberiana, temos a ordem social. Conceito que sinaliza a existência da institucionalização das açôes sociais regulares através de um conteúdo de sentido único tomado como máxima normativa das açóes. Em Kategorien, a ordem estatuída [gesatzte Ordnung] referia-se à regulamentação formal da ação (MWG I/12, [1908-1917], 2018. p. 408): quando, por conta da possibilidade objetiva, o conteúdo de sentido da ação individual corresponde em inúmeros pontos com o conteúdo de sentido da ordem. Se assumirmos a tese de Schluchter (2014) ${ }^{19}$, em 1913, além da ordem

18 "Uma ação societária com ordenamento do conteúdo e dos meios acordados racionalmente com referência a fins por todos os associados" (tradução da autora).

19 Em Kategorien, Weber fala explicitamente sobre a existência da gesatzte Ordnung: uma ordem que advém da ação societária. Ele não fala, entretanto, sobre a possibilidade de que a ação comunitária por acordo firme uma ordem. Weber explicita tão somente que a ação por acordo funciona "como se" uma ordem existisse. Já Schluchter afirma, com base nisso, que a ordem que advém da ação por acordo é a unsterstellte Ordung. Mas esse conceito, é importante esclarecer, não está no arquétipo formulado por Weber. 
estatuída (com base no interesse e na legalidade da ação societária), temos a "ordem suposta": ordem assegurada por um acordo tácito da ação por acordo. O conceito de ordem social de 1921 é mais profundo e complexo que o de 1913, pois Weber (MWG I/23, [1919-1920], 2013, p. 21-27) integra a vigência, a representação a legitimidade em um único modelo. Com isso, Weber funda um conceito de ordem que considera a existência (vigência) mental (representação) de uma norma que é tomada subjetivamente como máxima para a açáo no interior de um dado grupo organizado por um acordo (legitimidade). No Quadro 7, há a organização tipológica da teoria de ordem social de Kategorien.

Quadro 7 - Posições metodológicas e suas características

\begin{tabular}{|c|c|}
\hline 1913 & 1921 \\
\hline Plano macrossociológico & Plano macrossociológico \\
\hline $\begin{array}{c}\text { Ordem "suposta” } \\
\text { [unterstellte Ordnung] }\end{array}$ & $\begin{array}{c}\text { Ordem legítima } \\
\text { [legitime Ordnung] } \\
\text { Ordem estatuída } \\
\text { [gesatzte Ordnung] }\end{array}$ \\
\hline
\end{tabular}

Fonte: Elaborado pela autora (2020).

Em Kategorien, se assumirmos a tese de Schluchter (2014), temos a "ordem suposta" (assegurada por um acordo tácito da ação por acordo) e a ordem estatuída (com base no interesse e na legalidade da ação societária), conforme sistematizado no Quadro 7. Em Grundbegriffe, há um único conceito geral de ordem (a ordem legítima) calcado nas noçôes de legitimidade, vigência e representação. Como o elemento jurídico não é tão central quanto em 1913, há a inclusão do reconhecimento da legitimidade enquanto norma, máximas e deveres de qualquer espécie.

\section{Considerações finais}

Feitas as consideraçóes acerca das mudanças e permanências da estrutura conceitual de Sobre algumas categorias da Sociologia Compreensiva (1913) e Conceitos Sociológicos Fundamentais (1921), voltamos à pergunta que nos propusemos responder: "afinal, Weber possui duas Sociologias?”. Trata-se de uma pergunta norteadora, não necessariamente de uma 
indagação que necessita de uma resposta fechada e definitiva, o que não nos impede de responder que parece plausível afirmar que há duas versôes do texto que obedecem à mesma lógica micro-macro, cada qual com seus conceitos básicos sensivelmente distintos. Quer dizer, as duas versóes do texto possuem uma estrutura distinta em termos conceituais, mas ambas respeitam a mesma lógica dos níveis de análise: têm como ponto de partida a ação comunitária/ação social (nível micro) que, quando orientadas por um conteúdo de sentido comum, podem formar ordens sociais (nível macro). Não é o caso de afirmar, como faz Turner (1983), que os escritos weberianos da ação não são coerentes; afinal, o pensamento de Weber segue um percurso lógico (ação, relação, organização e ordem). Tanto em Kategorien quanto em Grundbegriffe, as ordens dependem intrinsecamente das ações e relaçóes sociais. A vinculação inversa também existe - de influência da ordem e organizaçóes sobre as ações e relaçôes -, mas em nível mais fraco. Acontece que as ordens existem pelas açôes e relaçôes; porém, as açóes podem se desenvolver sem as ordens.

Weber (1921) concebe a autonomia relativa do nível macrossocial com a diferenciação entre o conteúdo de sentido de orientação da ação individual e o conteúdo de sentido das relaçóes e ordens sociais (em nível coletivo). Portanto, ainda que os fenômenos em nível macro remetam sua constituição às açóes sociais, eles não são completamente reduzíveis à ação individual. Com isso, Weber conseguiu evitar a substancialização de conceitos, tais como "Estado", "igreja”, entre outros. Para Weber, tais formaçóes coletivas não existem como uma realidade sui generis como em Durkheim (2012). Ao contrário, suas existências dependem da constante legitimação e atuação das açóes individuais.

No debate entre Lichtblau (2015) (que defende uma marcante disparidade entre ambos os textos) e Schluchter (2014) (que assegura que a Sociologia de Weber passou apenas por um processo de amadurecimento conceitual sem mudança de concepção), adotamos uma posição intermediária. Aceitamos, em consonância com Schluchter (2014), a tese de que os textos passaram por um processo de amadurecimento teórico, de aperfeiçoamento conceitual e de abrangência de preocupação teórica. Não obstante, é necessário reconhecer que: 
1. Weber retoma e complexifica ideias embrionariamente desenvolvidas no seu texto preliminar (como é o caso do sentido subjetivamente visado da ação; de comportamentos motivados por afetos, valores e fins; das ordens sociais tomadas como máximas para a ação; das organizações sociais);

2. há ideias promissoras que, por outro lado, ele abandona (como é o caso da Einverständinishandeln);

3. há as ideias que ele mantém, mas sistematiza-as de maneira diferente (como é o caso da reformulação, ampliação e complexificação da noção de relação social; do racionalismo heurístico da ação social);

4. há as ideias que ele modifica substancialmente (como a mudança de uma perspectiva mais "jurídica" do conceito de ordem social, como a ordem estatuída, para uma mais "política”, como a ordem legítima; a aceitação de ações sociais orientadas pela tradição; a equivalência em termos racionais da ação de fins e da ação de valores).

Logo, se não há que falar em duas sociologias - no sentido de duas concepçóes paradigmáticas distintas, especialmente no que tange à relação macro/micro -, nem por isso se trata apenas de um novo arranjo de conceitos, no sentido de uma nova nomenclatura ou mesmo sequência de conceitos. Existem amadurecimentos e desdobramentos decisivos que são mais do que uma nova ordenação e que não deixam de representar mudanças teóricas, ainda que isso não implique superação por oposição, ou seja, não se pode falar em ruptura nem na existência do método I e do método II, em definitivo, do jovem Weber e do Weber maduro.

A Sociologia Compreensiva parece ser, de fato, em conformidade com o que propóe Rafael Farfán (2009), um capítulo da história da Sociologia. Cabe a nós, sociólogos brasileiros, impulsionados pelo empreendimento da Max Weber-Gesamtausgabe, ajudar a escrever o capítulo dessa história no Brasil. Há uma imensidão de material produzido sobre a obra de Weber no Brasil, algo que Merquior (1990) intitula de "indústria Weber". Mas, no que tange ao debate sobre a utilidade da teoria weberiana no atual curso da Sociologia Contemporânea, é necessário avançar. Esperamos que esse estudo possa ser um impulso nessa direção. 


\section{REFERÊNCIAS}

ALBERT, Gert. Holismo Metodológico Moderado: uma interpretação weberiana do modelo macro-micro-macro. Política \& Sociedade, Florianópolis, v. 15, n. 34, p. 43-76, 2016.

ALBERT, Gert et al. (org.). Das Weber-Paradigma. Tübingen: Mohr Siebeck, 2003.

BREUER, Stefan. Max Webers Herrschaftssoziologie. Frankfurt; New York: Campus, 1991.

COLliOT-THÉlÈnE, Catherine. Prefácio. In: WEBER, Max. Le savant et le politique. La profession et la vocation de savant. La profession et la vocation de politique. Paris: La Découverte, 2003. [s.p.].

DURKHEIM, Émile. As regras do método sociológico. Edipro: São Paulo, 2012.

ESSER, Hartmut. Das Weber-Paradigma, das Konzept des moderaten methodologischen Holismus und das Modell der soziologischen Erklärung. Kölner Zeitschrift für Soziologie und Sozialpsychologie, v. 58, n. 2, p. 340-349, 2006.

FANTA, Daniel. Sobre una de las categorías de la sociologia comprensiva. In: I CONGRESO LATINOAMERICANO DE TEORÍA SOCIAL, INSTITUTO DE INVESTIGACIONES GINO GERMANI, 1., Buenos Aires. Anais [...]. Buenos Aires: Universidad de Buenos Aires, 2015. [s.p.].

FARFÁN, Rafael. La sociología comprensiva como un capítulo de la historia de la sociologia. Sociológica, México, v. 24, n. 70, p. 203-214, ago. 2009.

GREVE, Jens. Wirtschaft und Gesellschaft. Soziologie (1919/1920). In: MÜLLER, Hans-Peter; SIGMUND, Steffen. Max Weber Handbuch: Leben - Werk - Wirkung. Stuttgart: J. B. Metzler, 2014. p. 287-328.

GROSSEIN, Jean-Pierre. De l'interprétation de quelques concepts wébériens. Revue française de sociologie, v. 46, n. 4, p. 685, jan. 2005a.

GROSSEIN, Jean-Pierre. Max Weber “à la française”? De la nécessité d'une critique des traductions. Revue française de sociologie, v. 46, n. 4, p. 883-904, 2005 b.

HABERMAS, Jurgen. Teoria de la acción comunicativa I: racionalidade de la acción y racionalización social. Santa Fé de Bogotá: Taurus Humanidades, 1999.

KALBERG, Stephen. Max Weber's comparative historical sociology. Chicago: University of Chicago, 1994.

KALBERG, Stephen. Max Weber's Comparative-Historical Sociology Today: Major Themes, Modes of Analysis, and Applications. London: Routledge, 2012.

KAUFMANN, Elisabeth. Oeuvres politiques (1895- 1919). Paris: Albin Michel, 2004.

LEPSIUS, Mario Rainer. "Economia e sociedade": a herança de Max Weber à luz da edição de sua Obra completa (MWG). Tempo social, São Paulo, v. 24, n. 1, p. 137-145, 2012. 
LEPSIUS, Mario Rainer. Institutionenanalyse und Institutionenpolitik. In: Institutionalisierung politischen Handelns. Studien zum Weber-Paradigma. Springer VS: Wiesbaden, 2013. p. 11-25.

LICHTBLAU, Klaus. Max Weber's Sociology as seen against the history of his work. Max Weber studies, Londres, v. 15, n. 2, p. 232-247, 2015.

MCCLELLAND, David C. The Achieving Society. New York: Harvard University, 1961.

MERQUIOR, José Guilherme. Rousseau e Weber: dois estudos sobre a teoria da legitimidade. Rio de Janeiro: Editora Guanabara, 1990.

MOMMSEN, Wolfgang. Max Weber's "Grand Sociology": The Origins and Composition of Wirtschaft und Gesellschaft. Soziologie, History and Theory, v. 39, n. 3, p. 364-383, 2000.

NORKUS, Zenonas. Max Weber und Rational Choice. Marburg: Metropolis-Verl., 2001.

ORIHARA, Hiroshi. From "A Torso with a Wrong Head" to "Five Disjointed Body-Parts without a Head": A Critique of the Editorial Policy for Max Weber-Gesamtausgabe I/22. Max Weber Studies, v. 3, n. 2, p. 133-168, 2003.

PIERUCCI, Antônio Flávio. Economia e sociedade: últimos achados sobre a "grande obra" de Max Weber. Revista brasileira de Ciências Sociais, v. 23, n. 68, p. 41-51, 2008.

ROSSI, Pietro. Max Weber: una idea di Occidente. Roma: Donzelli, 2007.

SCHLUCHTER, Wolfgang. Max Webers Beitrag zum "Grundriß der Sozialökonomik": Titelzusatz: Editionsprobleme und Editionsstrategien. Kölner Zeitschrift für Soziologie und Sozialpsychologie, v. 50, n. 2, p. 327-343, 1998a.

SCHLUCHTER, Wolfgang. Handlung, Ordnung und Kultur. Heidelberg: Mohr Siebeck, 2005.

SCHLUCHTER, Wolfgang. Acción, orden y cultura: estúdios para um programa de investigación em conexión com Max Weber. Prometeu: Buenos Aires, 2011.

SCHLUCHTER, Wolfgang. Os conceitos sociológicos fundamentais: a fundamentação da sociologia compreensiva de Max Weber. In: SCHLUCHTER, Wolfgang. O desencantamento do mundo: seis estudos sobre Max Weber. Rio de Janeiro: Editora UFRJ, 2014. p. 193-225.

SCHLUCHTER, Wolfgang. Max Weber Später Soziologie. Tübingen: Mohr Siebeck, 2016.

SCHMID, Hans Bernhard. Max Weber's Concept of Consensus. In: SCHMID, Hans Bernhard.. Plural Action Essays on Collective Intentionality and the and Social Sciences. Springer: Suíça, 2008. p. 271-312.

SCHWINN, Thomas. Max Webers Konzeption des Mikro-Makro Problems. Kölner Zeitschrift für Soziologie und Sozialpsychologie, v. 45, p. 220-237, 1993.

SELL, Carlos Eduardo. Max Weber e a racionalização da vida. Petrópolis: Vozes, 2013.

SELL, Carlos Eduardo. Weber no século XXI: desafios e dilemas de um paradigma weberiano. DADOS - Revista de Ciências Sociais, Rio de Janeiro, v. 57, n. 1, p. 35-71, 2014 a. 
SELL, Carlos Eduardo. Max Weber no Brasil: a interpretação do pensamento weberiano na pesquisa brasileira. Relatório de bolsa de produtividade em pesquisa 2010-2013. Florianópolis: Universidade Federal de Santa Catarina (UFSC), 2014 b.

SELL, Carlos Eduardo. Resenha de: (MWG I/12) - Sociologia Compreensiva e controvérsia sobre os valores. Escritos e Alocuçôes: 1908-1917. Tempo Social - Revista de sociologia da USP, v. 30, n. 3, p. 321-334, 2018.

SELL, Carlos Eduardo; PAULA JUNIOR, Josias de. A teoria sociológica e o debate micro-macro hoje. Política \& Sociedade, Florianópolis, v. 15, n. 34, p. 7-17, 2016.

TENBRUCK, Friedrich. Abschied von Wirtschaft und Gesellschaft. Zeitschrift für die gesamte Staatswissenschaft/Journal of Institutional and Theoretical Economics, n. 133, v. 4, p. 703736, 1977.

TURNER, Stephen. Weber on action. American Sociological Review, v. 48, p. 506-519, 1983.

VILLEGAS, Gil. Nota a nuestra segunda edición em español. In: WEBER, Max. Economía y sociedad. México: FCE, 2014. p.VII.

WEBER, Max. Economia e sociedade: fundamentos da sociologia compreensiva. Tradução de Regis Barbosa e Keren Elsabe Barbosa. Brasília: Editora Universidade de Brasília, 2015.

WEBER, Max. Metodologia das Ciências Sociais. Tradução de Augustin Wernet. São Paulo: Cortez; Campinas: Editora Unicamp, 2016.

MWG I/12. WEBER, Max. Verstehende Soziologie und Werturteilsfreiheit: schriften und reden [1908-1917]. Johannes Weiss; Sabine Frommer (ed.). Tübingen: Mohr Siebeck, 2018.

MWG I/23. WEBER, Max. Wirtschaft und Gesellschaft: Soziologie [1919-1920]. Knut Borchardt; Edith Hanke; Wolfgang Schluchter (ed.) Tübingen: Mohr Siebeck, 2013.

MWG II/8. WEBER, Max. Briefe 1913-1914. [1913-1914]. Organização de Mario Rainer Lepsius e Wolfgang J. Mommsen, com colaboração de B. Rudhard e M. Schön. Tübingen: J. C. B. Mohr (Paul Siebeck), 2003.

Recebido: 30/04/2020

Aprovado: 26/06/2020 


\section{Max Weber has two sociologies? Comparative analysis of the conceptual scheme of On some categories of comprehensive sociology (1913) and Fundamental sociological concepts (1921)}

\section{Abstract}

The critical republication of Max Weber's work, Max Weber-Gesamtausgabe, sparked a debate about changes and permanence of the Weberian lexicon. An example is a controversy between the essays Kategorien (1913) and Grundbegriffe (1921). Schluchter (2014) argues there was only a lexicon refinement without any conception change. Lichtblau (2015) contends there was an approach change: historical, in 1913; sociological, in 1921. Thus, the objective is to identify and discuss the analytical implications of the theoretical-conceptual changes made by Weber in Kategorien and Grundbegriffe to understand his conception development of Sociology. Therefore, the existence of a micro-macro model of upward causality is recognized in both Kategorien and Grundbegriffe. But, it is necessary to recognize the texts have gone through a process of theoretical maturation and conceptual improvement to modify the conceptual content of some fundamental categories of the Weberian scheme.

Keywords: Max Weber. Kategorien. Grundbegriffe. 